\title{
Technology for the Production of Sorghum for Grain in the Vertisols of Campeche, Mexico
}

\author{
Juan Medina-Méndez*, Jesús Manuel Soto-Rocha, Mirna Hernández-Pérez, \\ Joaquín Gómez-Tejero
}

Instituto Nacional de Investigaciones Forestales Agrícolas y Pecuarias, Campo Experimental Edzná, Campeche, México

Email: *medina.juan@inifap.gob.mx

How to cite this paper: Medina-Méndez, J., Soto-Rocha, J.M., Hernández-Pérez, M. and Gómez-Tejero, J. (2021) Technology for the Production of Sorghum for Grain in the Vertisols of Campeche, Mexico. Agricultural Sciences, 12, 666-683.

https://doi.org/10.4236/as.2021.126043

Received: July 25, 2020

Accepted: June 22, 2021

Published: June 25, 2021

Copyright $\odot 2021$ by author(s) and Scientific Research Publishing Inc. This work is licensed under the Creative Commons Attribution International License (CC BY 4.0).

http://creativecommons.org/licenses/by/4.0/

\begin{abstract}
This research was conducted in the state of Campeche, Mexico, between 2017 and 2018. On the one hand, the sorghum yield was explored in plots with Vertisol-type soils, which were supplied with rainwater. This had the purpose of knowing the results obtained by the producers in the area. On the other hand, an experiment was established with three factors: the genetic material of sorghum, planting density and fertilization. Finally, different varieties of soybeans and sorghum hybrids were also tested in large plots, to identify those that are best adapted to crop rotation. In the farmers' plots, the grain yield was between 4377 and $5543 \mathrm{~kg} \cdot \mathrm{ha}^{-1}$. The planting density was from 142,667 to 197,334 plants per hectare, which indicated that, for each unit that increased the planting density, the yield increased by 37.5 grams. The experiment with three factors indicated that the best planting density was 300 thousand plants per hectare, with a grain yield of $5176 \mathrm{~kg} \cdot \mathrm{ha}^{-1}$; and the best hybrids were DKS-32 and SYN5515, with grain yields of 5794 and 3791 $\mathrm{kg} \cdot \mathrm{ha}^{-1}$, respectively; likewise, the best dose of fertilizer was between 150 and $200 \mathrm{~kg} \cdot \mathrm{ha}^{-1}$ of diammonium phosphate, with a grain yield of $4527-4562$ $\mathrm{kg} \cdot \mathrm{ha}^{-1}$. In relation to crop rotation, the varieties that stood out for their yield were Huasteca 300 and Vernal, in the case of soybeans; and the hybrids DKS-32 and SYN5515, in sorghum. Soybeans suffered greatly in their early stages of development from the excessive moisture retained by the soil, while sorghum seemed to be little affected by the lack of rain; for this reason, advancing the sowing date in soybeans and consequently in sorghum, is a strategy that could benefit grain yield in both species.
\end{abstract}

\section{Keywords}

Vertisols, Tropics, Grains, Crop Rotations 


\section{Introduction}

In Campeche, sorghum currently occupies an area estimated to be between 20,000 and 25,000 hectares [1]. In this entity of the country, for many years now, sorghum was considered as an alternative for sowing in August and September, when due to deficiency or excess precipitation in June and July, corn and soybeans could not be sown and they were out of phase in time. Even though the option mentioned above is valid to date, today sorghum is also considered an excellent alternative to carry out crop rotations in those areas that are dedicated to the production of soybeans or corn, which depend on $100 \%$. Percent of rainwater supply. This method of sowing sorghum is carried out in the months of November and December, after soybeans and corn, in the clay soils regionally known as Káncab and Yaaxhom, which belong to the Luvisols [2] [3]. Regarding productivity, the first case mentioned results in a sorghum production system with average yields considered to be excellent for a crop that is supplied one hundred percent with rainwater and produces between 5.0 and 6.0 tons of grain per hectare. However, this sowing system is unusual in the state, as there are economic and social reasons why sorghum cannot compete with corn and soybeans, which are the predominant crops in the state, with which it coincides in time and space. The second case mentioned is characterized by a low-yield sorghum production system, ranging from 1.5 to 2.5 tons of grain per hectare on average, mainly due to the fact that Luvisoles soils have very low moisture retention. This affects the plant in its development and limits the productivity of sorghum as it is sown from November to December, when the rainy season is almost over. In this regard, Acevedo et al.; 2004 mentioned that the ferric oxide content of luvisols influences the stability of the aggregates to the action of water, and seems to provide them with a structure similar to that of sandy soils, which retain little moisture, despite the fact that the texture analyzes indicate that the clay content of this soil is higher than $60 \%$ [4]. The panorama changes remarkably when another scenario of sorghum production in this entity is considered; that is, when sown in Akalché-type soils, also known as vertisols. These soils are located mostly in the central and southern portion of the state, occupying part of the municipalities of Campeche and Champotón [3]. Here sorghum is planted mostly from October to November and occasionally in December, and produces yields between 3.0 to 5.0 tons of grain per hectare, since the type of soil that exists in these areas provides better conditions for development of the crop. A look at the events that occurred in past decades allows us to recall that the original vegetation of the vertisol soils, in a large part of this region, was eliminated between 1970 and 1985 to promote rice planting in the country; however, since rice planting declined, most of these areas were converted to livestock, while another part has been incorporated to agriculture, dedicating itself mainly to sorghum monoculture [5]. Some properties, such as the type of expandable clay and the pore size distribution, give vertisols high retention of moisture [6] 
[7] and therefore it meets more favorable conditions for the cultivation of sorghum than the Luvisol type soil during the autumn-winter cycle; and this allows to aspire to obtain in them a higher and more stable performance. Since much of the grain sorghum grown under these conditions is characterized by being a monoculture system, soil and rainwater, two important natural resources, are underutilized by producers. The soil remains idle for six to seven months (May to October), in which rainfall of 450 to $700 \mathrm{~mm}$ is recorded. Much of this rain is wasted because sorghum only takes advantage of the moisture retained in the soil and the little rain that is recorded in the months of November to February. This fact occurs due to a complex situation that includes several aspects such as the lack of culture of the producers in the use of crop rotations, the low price of the grain, the lack of knowledge of the specific technology for the site conditions, as well as the lack of infrastructure and work equipment. This is contrary to what is recommended by cambiar por Forjan and Manzo [8], who points out that crop rotation consists of the successive sowing of different plant species in the same soil over time; and it is considered as a management practice that seeks to maximize productivity per unit area, optimizing the use of resources. In this regard, it is widely held that rotations increase yields and allow sustained production, which is probably related to the increase in soil organic matter and the improvement of its physical properties, as well as to the interruption of the life cycle of pathogens and weeds, which may be responsible for the depression of yield in the continuous monoculture system [9] [10] [11]. Taboada et al., [12] reported that the stored carbon, the stability of the aggregates and the apparent density were studied in a soil of the Salado Basin. Argentina and highlighted that the magnitude of the effects generated by a crop rotation in the soil is conditioned by the plant species that are included and that differ in the volume of waste that they contribute to the soil, as well as in the architecture of their root system. By incorporating sorghum in crop rotations with soybeans, different benefits are obtained: sorghum contributes up to 15 tons of stubble per hectare, which favors the growth of the successor crop, since it increases organic matter, thereby which improves the structure of the soil helping to maintain its porosity and in turn it acts positively on the infiltration of water into the subsoil. Another advantage of sorghum is that it has a good behavior in the face of water deficit, so its yields are stable, adapting to variable climatic conditions. Some reports indicate that sorghum needs $400 \mathrm{~mm}$ of rain from sowing to harvest to obtain good yields, but with $250 \mathrm{~mm}$ its yield is acceptable to produce profitably [13] [14] [15]. In relation to the nutrition of crops sown in rotation, in vertisol soils of Uruguay, it is mentioned that soybeans take advantage of the potassium contained in the vegetable residues of rice, at the same time that it provides nitrogen for its nutrition [16]. The contribution of nitrogen to the soil by the cultivation of soybeans ranges from 60 to $100 \mathrm{~kg}$ per hectare. This nitrogen is the product of the symbiosis that the plant establishes with the soil bacteria and serves to immediately nourish the next crop in the rotation due to the fact that the soybean 
leaves have an adequate carbon/nitrogen $(\mathrm{C} / \mathrm{N})$ ratio, which allows rapid decomposition [17]. On the other hand, the management of soybeans as a monoculture in Argentina has caused the appearance of nutritional imbalances in the soil and this is a negative aspect caused by the scarce application of fertilizers, being a clear sign of deterioration due to the drastic decrease in the organic matter and available phosphorus in the soil [18].

Planting density is a fundamental factor in taking advantage of water, soil fertility and solar energy for the benefit of production [19]. Proper seeding density helps to solve the problem of low grain yield. If a low density is used, there is a negative effect on yield because there is no balanced competition between sorghum and weeds, and evaporation of water from the soil increases because the sun's rays hit the soil surface directly by a longer time. On the other hand, if the sowing density is high, the competition for water among the plants of the same crop increases, which also affects the yield, especially if the crop is totally dependent on rainwater [20]. Wade and Douglas [21] studied the importance of the interaction of the days to maturation of grain sorghum with the sowing density, in three hybrids. They analyzed the stability of their response in yield and other characters, from which they found that faster maturation was higher in environments characterized by water stress, while late maturity was higher in less stress environments, due to this the early hybrids had a more stable performance. Likewise, they point out that, in areas with high risk of drought, where yields are generally low, the planting density of 50 to 100 thousand plants per hectare may have a better performance in yield. For their part, Berenguer and Faci [22] studied the behavior of the sorghum yield components in areas of marginal humidity and very little irrigation; pointed out that this crop tolerates high temperatures and drought and, because of this, is more suitable than corn in environments with low available humidity. They found a linear relationship between the irrigation water applied, the total dry matter, the grain yield and the harvest index, in the planting densities used. They also added that the sowing density did not significantly affect the grain yield since there were important yield compensation processes, among which they mention the higher production of tillers, greater number of grains per panicle and a higher grain weight at the lowest plant densities. These results indicated that a high density of plants did not present productive advantages in grain yield in this crop. On the other hand, the results obtained by Tabo et al., [23] indicated that sorghum is grown mostly in soils with residual moisture, which exposes the crop to drought stress in the terminal stages of the plant life cycle. They argued that it is possible to improve crop efficiency by using appropriate plant densities and their study showed that yield can be improved by manipulating the plant population and using early cultivars. Rivero [24] carried out a study of phosphoric fertilization in sorghum, in Tamaulipas Mexico. He studied factors such as planting density and two humidity regimes (two and three auxiliary irrigations). He found statistical differences in performance between humidity regimes; and pointed out that the optimum 
density under conditions of adequate humidity was 231,511 plants hectare (20 plants per linear meter), which registered a yield of $7911 \mathrm{~kg} \cdot \mathrm{ha}^{-1}$, while the optimum density under humidity limitation in the filling stage of grain was 197,674 plants per hectare (17 linear meter plants) with a yield of $7159 \mathrm{~kg} \cdot \mathrm{ha} \mathrm{a}^{-1}$. Likewise, it indicated that the optimal economic dose of phosphorus was $63.42 \mathrm{Kg}$ per hectare. Stevens and Dunn [25] tested different doses of nitrogen fertilization in sorghum, verifying the effect of a low planting density (70 thousand plants per hectare) and a normal planting density (210 thousand plants per hectare) on the yield of grain. They found no interactions between fertilization doses and planting densities. The low plant populations did not differ in yield from the normal populations as they produced larger panicles thus compensating for the yield. However, they emphasize that when the low population is caused by failures in the operation of the sowing machinery, there may not be this compensatory effect and yield declines. Vertisol-type soils in the state of Campeche are clayey and have a high moisture retention capacity [26], generally they are poor in phosphorus and with high calcium content, conditions that are usually negative. for some crops [27]. Likewise, these soils have a high potassium content, sufficient to maintain an excellent production of grains and vegetables and abundant organic matter, which provides sufficient nitrogen to crops [28]. Sorghum must have in the soil values of $85 \mathrm{~kg}$ of nitrogen, $35 \mathrm{~kg}$ of phosphorus and $95 \mathrm{~kg}$ of potassium per hectare available for the plant, to maintain yields of 3.5 tons per hectare on average; therefore, phosphorus is considered to be the most determining element in production [29].

The objective of the research was to evaluate different technological factors of production to generate technical recommendations applicable to the cultivation of sorghum sown in the autumn-winter cycle in vertisol soils in the state of Campeche. The technological factors studied were seed density, fertilization, varieties, and crop rotation. Variables such as grain yield and days of flowering were emphasized.

\section{Materials and Methods}

\subsection{Exploration of Sorghum Yield in Commercial Vertisol-Type Soil Plots}

\subsubsection{Characteristics of the Selected Plots}

Four producer plots with an area between 25 and 50 hectares were selected. These plots had a very similar sowing date (October 15 to 30,2017), the soil type was Vertisol [30] and the sowing method was with a mechanical seeder, it was supplied only with rainwater and residual soil moisture. Fertilization was done very sparingly (approximately $100 \mathrm{~kg}$ of ammonium phosphate per hectare) and hybrid seed was used in all of them. The plots were identified as Alfredo V. Bonfil 1 and Alfredo V. Bonfil 2; Melchor Ocampo and Kikab, which was related to the name of the localities where the farmers who owned these plots resided. 


\subsubsection{Sampling to Evaluate Performance}

To sample the yield, five $8 \mathrm{~m}^{2}$ sites were selected, one at each vertex of the plot and one in the center.

\subsubsection{Harvest Date and Statistical Analysis of the Information}

The harvest was carried out from February 6 to 20, 2018. For the statistical analysis of the yield, a Completely Random Design was used, with four treatments and four repetitions. The treatments were the localities and the repetitions were the samplings carried out. The comparison of means was carried out with the Duncan DMS method $(\mathrm{p}=0.05)$.

\subsection{Experimentation}

\subsubsection{Treatments Evaluated}

Five hybrid materials are used: DKS-32, DAS-4430, SYN5515, 85P20 and AMBAR. Five fertilization treatments: control (without fertilizer), 50, 100, 150 and 200 $\mathrm{kg} \cdot \mathrm{ha}^{-1}$. Ammonium phosphate was used because this fertilizer is the most widely used source of fertilization for crops in the region [31] [32] [33]. Finally, five planting densities were also considered: 100, 150, 200, 250 and 300 thousand plants per hectare.

\subsubsection{Study Site Features}

It was planted in the locality called Edzná Experimental Site $\left(19^{\circ} 36^{\prime} 34.97^{\prime \prime N}\right.$; $90^{\circ} 13^{\prime} 17.32^{\prime \prime} \mathrm{W}$ and $24 \mathrm{~m}$ altitude), owned by the National Institute of Agricultural Forestry Research (INIFAP). The soil was Vertisol type, whose chemical analysis registered a phosphorus content of $1.40 \mathrm{ppm}$; and a nitrate content of $33.4 \mathrm{ppm}$ that were considered as low and high, respectively [34]. The crop was supplied with the moisture retained in the soil, three rains that added $45 \mathrm{~mm}$ and two auxiliary irrigations.

\subsubsection{Sowing and Harvesting Dates}

The sowing date was January 16, 2018 and the harvest from May 5 to 8, 2018.

\subsubsection{Technological Management of the Crop}

Weed control was carried out in two ways: the first was chemically and for this, 2,4-D amine $\left(0.5 \mathrm{l} \cdot \mathrm{ha}^{-1}\right)$ was applied, when the plant was 20 days old. The second weed control was done mechanically after 35 days, using an iron implement that removed the soil and was powered by a tractor. The pests were controlled with Espinetoram $\left(0.075 \mathrm{l} \cdot \mathrm{ha}^{-1}\right)$ in the case of Spodoptera frugiperda, and with Imidacloprid $\left(0.5 \mathrm{l} \cdot \mathrm{ha}^{-1}\right)$ in the case of the yellow aphid (Melanaphis sacchari). All the fertilizer used in the different treatments was applied at sowing.

\subsubsection{Statistical Analysis of Grain Yield}

As an experimental plot, there was a row of five meters long and the separation between rows was $80 \mathrm{~cm}$. A randomized block design with two repetitions was applied. The data were statistically analyzed as factorial $\mathrm{AxBxC}$, using the Infos- 
tat software. Fisher's LSD method $(\mathrm{p}=0.15)$ was used to compare the means.

\subsection{Study of Crop Rotation in Vertisol-Type Soils}

\subsubsection{Study Site Location}

The investigation was carried out in the town of Valle de Quetzalcoatl $\left(19^{\circ} 13^{\prime}-\right.$ $\left.54.55^{\prime \prime N} ; 90^{\circ} 15^{\prime} 08.19^{\prime \prime} \mathrm{W}\right)$, which is located in the municipality of Champotón. Crop rotation was studied in order to take advantage of the soil in a more comprehensive and sustainable way, as well as the humidity from the rains, and the residual humidity retained in the soil, in order to obtain two crops of grains at a time. Year in the same place.

\subsubsection{Genetic Material That Integrated Crop Rotation}

The crop rotation had as members the soybean crop sown in summer and sorghum sown in winter; six varieties of soybeans were used; Huasteca 200, Huasteca 300, Huasteca 400, Tamesí, Vernal and Luziania; as well as five grain sorghum hybrids: DKS-32, DAS-4430, SYN5515, 85P20 and AMBAR.

\subsubsection{Characteristics of the Plot Used for Rotation}

The plot had an approximate area of 2.0 hectares. Soybean varieties and sorghum hybrids were planted in the form of adjacent strips, with a spacing of $80 \mathrm{~cm}$ between rows and a length of approximately $200 \mathrm{~m}$.

\subsubsection{Technical Management of Crops}

\section{1) Soil preparation}

Regarding the sowing season, soybeans were sown in July and sorghum in December. Soil preparation for planting was carried out as traditionally done by farmers in the region, preparing the soil through three steps of disc harrow at the beginning of soybean planting. Also included, every eight furrows, was a trench ditch 1.10 to $1.20 \mathrm{~m}$ wide and $35 \mathrm{~cm}$ deep, which functioned as surface drainage to dislodge excess water from the rains, which occurred abundantly from July to September. For the sorghum planting, the soil was not removed, only herbicide was applied to eliminate the weeds.

\section{2) Planting density and fertilization}

The sowing density was 250 thousand plants per hectare for soybeans, with approximately $32 \mathrm{~kg}$ per hectare of seed; and from 200 to 250 thousand plants per hectare in sorghum, with $8-9 \mathrm{~kg}$ of seed per hectare. The fertilization of both crops was carried out at the time of sowing. $100 \mathrm{~kg}$ of ammonium phosphate (DAP) per hectare were applied to soybeans, while $200 \mathrm{~kg}$ of this same fertilizer were applied to sorghum.

\section{3) Weed and pest control}

Weed control in soybeans was done with a pre-emergent herbicide, one day after sowing, for which Acetochlor (1.5 to $2.0 \mathrm{~L}$ per hectare) was used. Later, Imazetapril (1.0 L per hectare) was used to eliminate $10 \mathrm{~cm}$ tall weeds. In sorghum, Atrazine was applied to prevent the outbreak of broadleaf weeds, mixing 
with Glyphosate (2.0 L + $1.0 \mathrm{~kg}$ per hectare), to eliminate some grasses that had germinated and that still had very little development. This last herbicide application was made one day after sowing in both crops. Subsequently, to keep the crop clean until harvest, the weeds that emerged between the rows were fought mechanically using machinery in the case of large plots, and manually, in the case of the experiment. This was done both in soybeans between 35 and 40 days after sowing as recommended by Magallanes et al., [35]. The pests that appeared in soybeans were $D$. balteata in soybeans [36], which was fought with Dimethoate ( $0.75 \mathrm{~L}$ per hectare) and Stigmene acrea, which was fought with Espinetoram (75 $\mathrm{ml}$ per hectare). In sorghum, the pest that required control was the yellow aphid (Melanaphis sachari) and this was done with an application of Imidacloprid (0.5 L per hectare).

\subsubsection{Variables Considered}

The main study variable was grain yield at $14 \%$ moisture. Some auxiliary variables were also recorded such as the height of the plant, the days until flowering (counted from sowing). At the time of harvest, the number of pods in soybeans was counted, as well as the total number of plants and effective plants (plants with panicles in the case of sorghum).

\subsubsection{Statistical Analysis of the Results}

In the case of crop rotations, a randomized block design was used to analyze the sorghum and soybean yields obtained from the samplings. The data from days to flowering and days to harvest, of the soybean varieties, as well as the sorghum hybrids, were presented as an average and were used to know in more detail the life cycles of the cultivars involved.

\section{Results and Discussion}

\subsection{Exploration of Sorghum Yield in Commercial Plots}

There was no significant difference between treatments or repetitions according to the $\mathrm{F}$ test $(\mathrm{p}=0.05)$. This indicated that there was very little variability in the grain yield obtained by the producers of the different plots that included observation points. The average yield fluctuated between 4377 and $5543 \mathrm{~kg} \cdot \mathrm{ha}^{-1}$, being the plot named Alfredo V. Bonfil 1, the one with the highest yield, contrary to Kikab, which obtained the lowest value. This yield was higher than that reported by Villalobos [33], perhaps influenced by the date of planting and the type of soil, which represent the most ideal environment for this crop in Campeche. In these producer plots the average population density estimated at harvest was 166,833 plants per hectare, and fluctuated from 142,667 to 197,334 plants per hectare. The correlation of population density with grain yield was positive. The regression analysis (Figure 1) was represented by the equation $y=0.0375 x-$ $1374(\mathrm{R} 2=0.8643)$, which indicated that under the conditions in which this study was carried out, for each unit that the population density, the yield increased 37.5 grams, a result similar to what was reported by Zamora et al., [37]. 


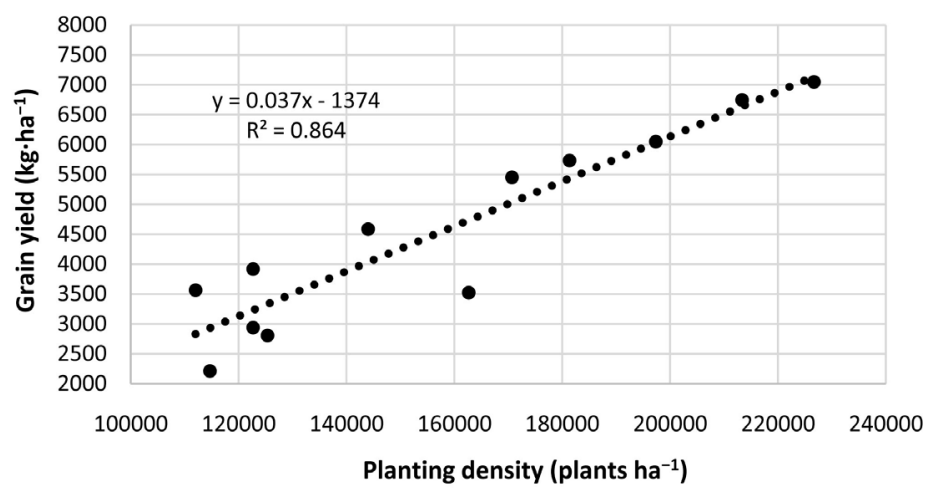

Figure 1. Relationship between yield and planting density of sorghum for grain in the state of Campeche.

\subsection{Experimentation}

Analysis of variance of grain yield reported highly significant differences in all sources of variation. In accordance with the above, the factor means comparison test was carried out (Table 1).

\subsubsection{Fertilization}

As could be observed, the control without fertilizer and the dose of $50 \mathrm{~kg}$ of diammonium phosphate (DAP) per hectare were statistically equal in yield, and lower than the rest of the treatments. Likewise, the best fertilization dose was between 150 and $200 \mathrm{~kg} \cdot \mathrm{ha}^{-1}$ of DAP, with average yields of $4527-4562 \mathrm{~kg} \cdot \mathrm{ha}^{-1}$. These results were in agreement with those obtained by Rivero [24] and Stevens and Dunn [25]. The laboratory results, obtained prior to the study, had diagnosed a phosphorus deficiency in the soil, so this response to phosphoric fertilization was expected according to the studies of Sahrawat [27] and Gambaudo [29]. The magnitude of this response was estimated at approximately $1200 \mathrm{~kg}$ per hectare, which contributed a net profit of $\$ 2310$ pesos per hectare at the current price of $\$ 3300$ per ton of grain in 2020 in this region of the country.

\subsubsection{Planting Density}

The sowing density that reported the lowest yield was 100,000 plants per hectare, being statistically lower than the others. The best sowing density was 300 thousand plants per hectare, with $5176 \mathrm{~kg} \cdot \mathrm{ha}^{-1}$, these results differ from that reported by Berenguer and Faci [22] and Schatz et al., [19], who found no differences in yield to different plant densities and indicate that sorghum is a crop that compensates for the low population by emitting larger panicles and grains; but they coincide with that reported by Tabo et al., [23], Cicchino [38] and Stevens and Dunn [25].

\subsubsection{Genetic Material Evaluated}

Regarding the hybrids, the best of them was DKS-32, with $5794 \mathrm{~kg} \cdot \mathrm{ha}^{-1}$, followed by SYN5515, with $3791 \mathrm{~kg} \cdot \mathrm{ha}^{-1}$; the hybrid $85 \mathrm{P} 20$ registered the lowest yield $\left(1755 \mathrm{~kg} \cdot \mathrm{ha}^{-1}\right)$, presenting at the same time a greater affectation of the yellow 
Table 1. Comparison test of means of grain yield in fertilization, planting density and genetic material.

\begin{tabular}{cccccc}
\hline $\begin{array}{c}\text { Hybrids } \\
(\text { Name })\end{array}$ & $\begin{array}{c}\text { Yield } \\
\left(\mathrm{kg} \cdot \mathrm{ha}^{-1}\right)\end{array}$ & $\begin{array}{c}\text { Fertilization } \\
\mathrm{DAP}^{*}\left(\mathrm{~kg} \cdot \mathrm{ha}^{-1}\right)\end{array}$ & $\begin{array}{c}\text { Yield } \\
\left(\mathrm{kg} \cdot \mathrm{ha}^{-1}\right)\end{array}$ & $\begin{array}{c}\text { Planting density } \\
(\text { Thousands })\end{array}$ & $\begin{array}{c}\text { Yield } \\
\left(\mathrm{kg} \cdot \mathrm{ha}^{-1}\right)\end{array}$ \\
\hline DKS-32 & $5794 \mathrm{a}^{\star *}$ & 200 & $4562 \mathrm{a}^{* *}$ & 300 & $5176 \mathrm{a}^{\star *}$ \\
SYN5515 & $3791 \mathrm{~b}$ & 150 & $4527 \mathrm{a}$ & 200 & $4109 \mathrm{~b}$ \\
DAS-4430 & $3699 \mathrm{~b}$ & 100 & $3941 \mathrm{~b}$ & 250 & $3946 \mathrm{bc}$ \\
AMBAR & $3533 \mathrm{~b}$ & 50 & $3372 \mathrm{c}$ & 150 & $3659 \mathrm{c}$ \\
85 P20 & $1755 \mathrm{c}$ & 0 & $3142 \mathrm{c}$ & 100 & $2651 \mathrm{~d}$ \\
\hline
\end{tabular}

${ }^{\star} \mathrm{DAP}=$ ammonium phosphate, ${ }^{\star *} \mathrm{Quantities}$ with the same letter are not statistically different. Duncan test $($ DMS $\mathrm{p}=0.05)$.

aphid, a fact that coincided with the Perales report [39]. Likewise, this pest was reported for the first time in 2015 by producers of the entity and agrees with the reports by Rodríguez and Terán [40] and Cortez [41].

\subsubsection{Fertilization and Phenology of the Plant}

The plant's response to fertilization, in its phenology, was manifested in a shortening of the interval of days elapsed from sowing to flowering when the results of the best fertilization dose were compared with those of the treatment without fertilizer (Figure 2). This fact could be attributed to the effect of phosphoric fertilization according to the reports by Mixquitla and Villegas [42] and Álvaro [43], who point out that phosphate accelerates maturation and seed production, which induces growth, more vigorous and faster maturation of the plant when the phosphorus content in the cell is adequate.

In the treatment without fertilizer DKS-32 and SYN5515 (the early cycle hybrids) had an average of 73 days from sowing to flowering, however, in the best doses this interval was shortened by 14 days, reaching the flowering time to 57 days. Regarding the DAS4430, 85P20 and AMBAR hybrids (the intermediate cycle hybrids), they had an average of 88 days from sowing to flowering in the treatment without fertilizer, but at the best dose this interval was shortened by 23 days, reaching flowering time at 65 days. This reduction in days to flowering was associated with an increase in grain yield according to the average that was recorded in the different doses of fertilizer (Figure 3), a result that coincides with that indicated by Wade and Douglas [21] and Tabo et al., [23].

\subsection{Crop Rotation}

\subsubsection{Days to Flowering and Harvesting in Crops}

In both species, important phenotypic characteristics were manifested that must be taken into account in crop rotation. Soybean varieties, such as Huasteca 400 and Luzianía registered 41 days from sowing to flowering, very similar to the Huasteca 300, Vernal and Tamesí varieties that registered 46 days; being the Huasteca 200 variety the latest of all, with 55 days (Table 2). As it could be 


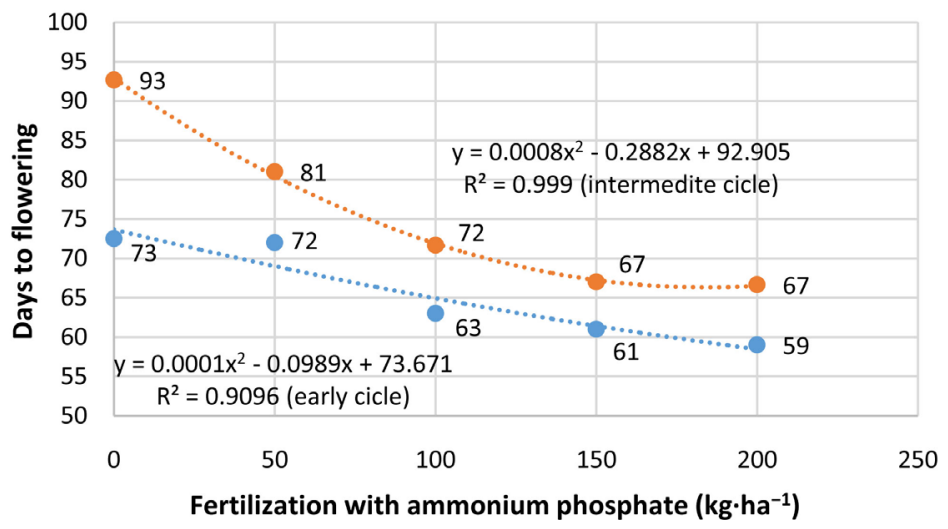

Figure 2. Relationship between fertilization and phenology in early and intermediate cycle sorghum hybrids in the state of Campeche.

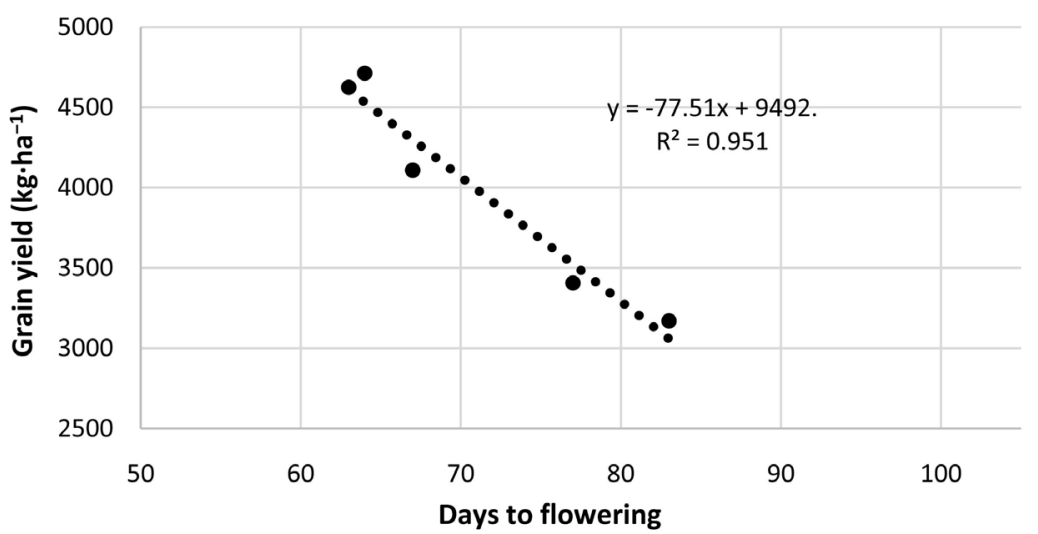

Figure 3. Relationship between days from planting to flowering and sorghum yield in Vertisol-type soils of the Campeche state.

Table 2. Days elapsed from planting to flowering and harvesting in six soybean varieties grown in Vertisol-type soils in the state of Campeche.

\begin{tabular}{ccccc}
\hline Variety & Planting date & Days to flowering & Harvest date & Days to harvest \\
\hline Huasteca 200 & 55 & December 21 & 141 \\
Huasteca 300 & 46 & December 4 & 124 \\
Huasteca 400 & August 1 & 41 & December 2 & 122 \\
Luzianía & 41 & December 1 & 121 \\
Vernal & 46 & November 27 & 117 \\
Tamesí & 46 & December 4 & 124 \\
\hline
\end{tabular}

observed, all the soybean varieties registered variations in their phenology with respect to that indicated by Magallanes et al., [35], this consisted of a shortening in the interval of the days from sowing to flowering. The soybean varieties were harvested between 117 and 141 days after sowing. In sorghum, the materials with the earliest cycle, DKS-32 and 5515, flowered between 53 and 54 days after sowing, while DAS-4430, 85P20 and Ambar, the materials with a slightly longer 
cycle, they flowered between 56 and 59 days. The literature indicates that the physiological maturity of the grain in sorghum occurs from 25 to 45 days after flowering [44], in such a way that the maturity at harvest took place approximately 35 days later. Of this stage, that is, 120 to 127 days after sowing (Table 3 ), indicating that none of the hybrids had a late cycle, which was perhaps influenced by the high temperature of the months of April and May in the entity, which goes $30^{\circ} \mathrm{C}$ to $34^{\circ} \mathrm{C}$ maximum.

\subsubsection{Soybean Grain Yield}

The average yield of the soybean varieties in this study was $1758 \mathrm{~kg} \cdot \mathrm{ha}^{-1}$ (Figure 4), which is considered lower than the averages reported for the state of Tamaulipas [35], and the state of Campeche [31]. The statistical analysis registered a coefficient of variation that was considered high $(33.41 \%)$, indicating that there were some factors out of control that could have affected the investigation; however, there were highly significant differences between the varieties, which indicated that at least one of them had a different behavior from the others. The low yields indicate that the excess moisture that prevailed in the early stages of crop development had a negative effect on grain yield. It was evident that the plants produced fewer roots and fewer foliage, fewer pods and smaller grains; The formation of nodules in the root was also affected, as indicated by Steduto et al., [45], and nutrient absorption was reduced.

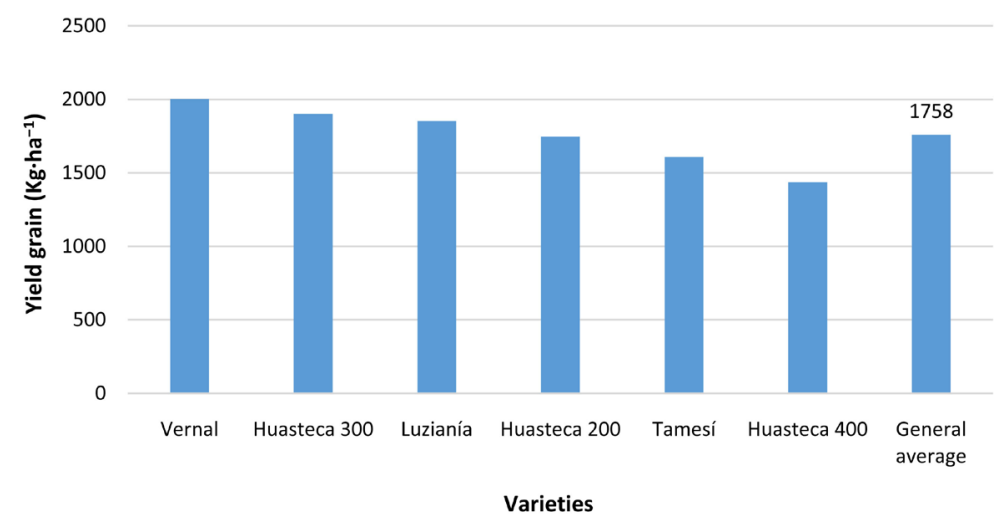

Figure 4. Average yield of six soybean varieties grown in Vertisol-type soils in the state of Campeche.

Table 3. Days elapsed from planting to flowering and harvesting in five sorghum hybrids grown in Vertisol-type soils in the state of Campeche.

\begin{tabular}{ccccc}
\hline Variety & Planting date & Days to flowering & Harvest date & Days to harvest \\
\hline DKS-32 & 54 & April 22 & 120 \\
DAS4430 & 57 & April 29 & 127 \\
SYN5515 & December 23 & 53 & April 22 & 120 \\
85P20 & 59 & April 29 & 127 \\
AMBAR & 56 & April 29 & 127 \\
\hline
\end{tabular}




\subsubsection{Sorghum Grain Yield}

Sorghum in rotation with soybeans had an estimated average yield of $5816 \mathrm{~kg} \cdot \mathrm{ha}^{-1}$, which was comparable to those obtained by producers who sow sorghum in monoculture, on the sowing date considered most appropriate. The analysis of Figure 5 showed that DKS-32 and SYN5515 were the hybrids with the highest yield, with 5985 and $5950 \mathrm{~kg} \cdot \mathrm{ha}^{-1}$, respectively, although they only outnumbered the hybrid DAS4430, which obtained 5642 per $325 \mathrm{~kg} \cdot h a^{-1}$. This general performance of the yield was higher than that reported by Villalobos [33] and was attributable in part to the density of sowing and fertilization, which were higher than those used commercially by producers, a fact that was confirmed by comparing these results with those obtained in the exploration of the sorghum yield in commercial plots such as, for example, in the town of Alfredo V. Bonfil 1, whose data were described in previous paragraphs.

\subsubsection{Accumulated Rainfall at the Study Site and Proposal for the Most Viable Crop Rotations}

The accumulated precipitation in the year in the study locality was $1248 \mathrm{~mm}$, as indicated in Figure 6; of this amount, soybeans received $821 \mathrm{~mm}$ from sowing to harvest, while sorghum only received $109 \mathrm{~mm}$. This explains why soybeans suffered due to excessive soil moisture and sorghum suffered from drought, although in the end this fact was overcome. Therefore, in the climatic conditions in which the research was carried out, the sorghum-soybean crop rotation could be carried out with more success using the sorghum hybrids DKS-32 and SYN5515, and the Huasteca 300 and Vernal soybean varieties. The results of the climatic behavior in the study area indicate that the soybean sowing date should be modified, starting sowing on June 16 and ending on July 15 so that it is less affected by excessive humidity. From the soil and thus obtain higher yields. On the other hand, in sorghum, the sowing date should be from November 1 to 30 to prevent it from suffering too much water stress and to also try to take better

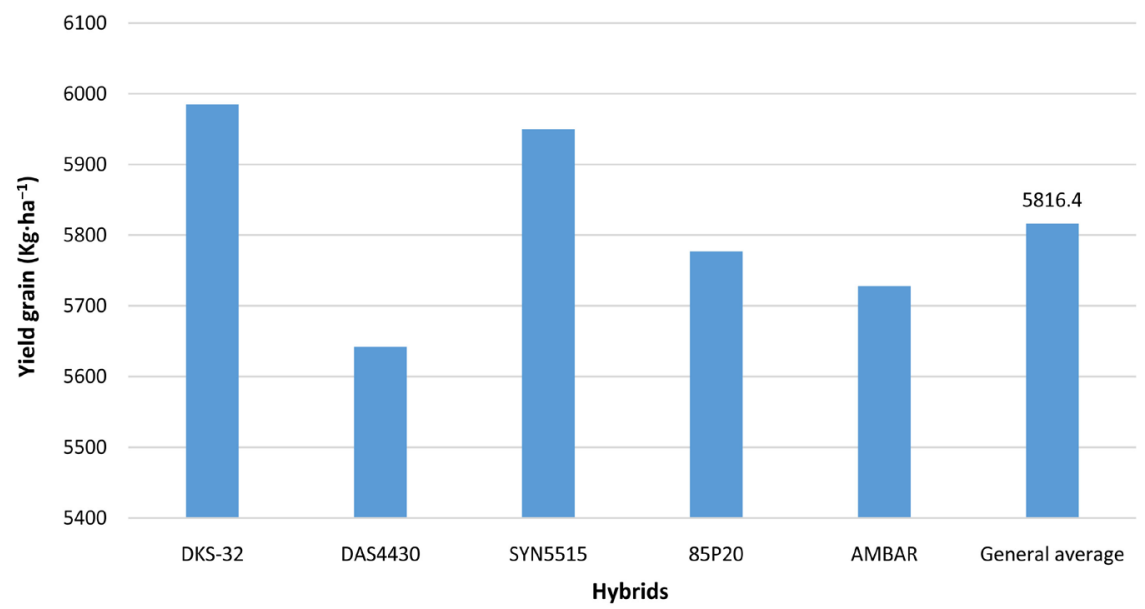

Figure 5. Average yield of five sorghum hybrids grown in Vertisol-type soils in the state of Campeche. 


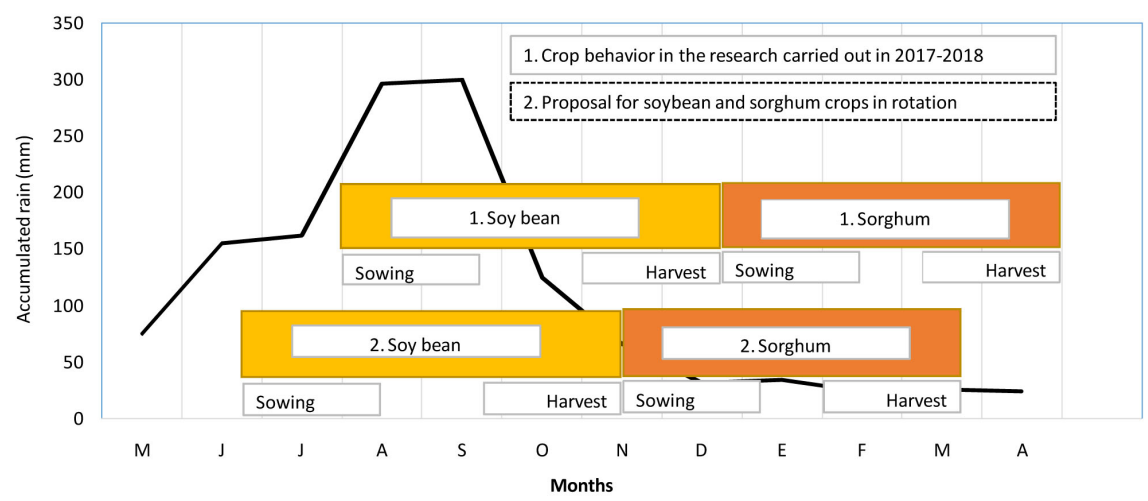

Figure 6. Accumulated rainfall from March 2017 to April 2018 and its relationship with the life cycle of crops in the research and proposal that was developed based on the results.

advantage of the moisture contained in the soil, as well as the low rainfall of the months from January to March so that the plant develops in better conditions. In addition to the absence of rains in this part of the year, there is another negative climatic factor for the development of the plant, which is the high temperature of the months of March, April and May, which occurs in this region of the country [46], which undoubtedly affected the performance of the sorghum hybrids and allowed the selection of those with the best performance [23] [47] [48].

\section{Conclusions}

Yield exploration on commercial plots reported fairly acceptable average returns; however, the analysis seems to indicate that the producers are using a low population density and this could be a limitation to achieve high yields given that the plots that were included in this part of the study were sown on dates that allow better use of the humidity present at this time of year; therefore, they could be recommended to increase the number of plants planted per hectare.

The analysis of the behavior of factors such as hybrids, fertilization doses and planting density, indicated that there is a need to make adjustments in the current production technology. Derived from the results of this research it is proposed to use the sorghum hybrids DKS-32, SYN5515 and DAS4430 with a density of 300 thousand plants and a fertilization of 150-200 kg of Ammonium Phosphate per hectare.

On the other hand, when the sorghum-soybean crop rotation was used, it was observed that it is possible to obtain two grain crops per year in the same field, taking advantage of the rain and the humidity that the soil manages to store. The Huasteca 300 and Vernal soybean varieties were the most recommended to be sown in rotation with any of the three sorghum hybrids mentioned above. Regarding the life cycles of soybeans and sorghum, it was observed that both soybeans and sorghum occupy 120 to 130 days from sowing to harvest; however, it is necessary to bear in mind that there may be slight variations in this time interval, depending on the variety of soybeans and the sorghum hybrid used. 


\section{Conflicts of Interest}

The authors declare that they have no conflicts of interest with respect to the publication of this document.

\section{References}

[1] Agricultura (2020). Reporte del mercado de sorgo. $15 \mathrm{p}$. https://www.cima.aserca.gob.mx/work/models/cima/pdf/cadena/2020/Reporte_mer cado_sorgo_200120.pdf

[2] Duch, G.J. (2005) La nomenclatura maya de suelos: Una aproximación a su diversidad y significado en el sur del estado de Yucatán. Revista de Geografía Agrícola, 34, 55-74. https://www.redalyc.org/pdf/757/75703405.pdf

[3] Palma-López, D.J., Zavala-Cruz, J., Bautista-Zuñiga, F., Morales-Garduza, M.A., López-Castañeda, A., Shirma-Torres, E.D., Sánchez-Hernández, R., Peña-Peña, A.J. and Tinal-Ortiz, S. (2017) Clasificación y cartografía de suelos de Campeche. Revista Agroproductividad, 19, 71-78. http://www.inafed.gob.mx/work/enciclopedia/EMM04campeche/mediofisico.html

[4] Medina-Méndez, J., Volke, H.V., González, R.J., Galvis, S.A., Santiago, C.M.J. and Cortés, F.I. (2006) Cambios en las propiedades físicas del suelo a través del tiempo en los sistemas de maíz bajo temporal y mango bajo riego en luvisoles del estado de Campeche. Universidad y Ciencia, 22, 175-189. https://www.redalyc.org/articulo.oa?id=15422208

[5] TRIBUNA (2017) Ganadería y sorgo sustituyen al arroz. https://tribunacampeche.com/local/2017/11/05/ganaderia-sorgo-sustituyen-al-arroz

[6] Acevedo-Sandoval, O., Ortiz-Hernández, E., Cruz-Sánchez, M. and Cruz-Chávez, E. (2004) El Papel De Óxidos De Hierro En Suelos. Terra Latinoamericana, 22, 485-497. https://www.redalyc.org/pdf/573/57311096013.pdf

[7] Ibáñez, J.J. (2011) Vertisoles: Uso y Manejo. http://www.madrimasd.org/blogs/universo/2011/10/21/140108

[8] Silva, P., Vergara, W. and Acevedo, E. (2015) Rotación de cultivos. Instituto de Investigaciones Agropecuarias Universidad de Chile.

https://inta.gob.ar/sites/default/files/inta___rotaciones_y_secuencias_de_cultivos_e n_la_region_mixta_cerealera_del_centro_sur_bonaerense.pdf

[9] Astier, M. and Pérez, E. (1998) Rotaciones y Asociaciones de Cultivos en Sistemas de Maíz en Zonas Templadas, Memoria del Taller Nacional, 29 y 30 de abril, Pátzcuaro, Michoacán, México. CIMMYT. 71 p. https://repository.cimmyt.org/xmlui/bitstream/handle/10883/961/66291.pdf

[10] Chaves, N.F. and Araya, C.M. (2012) Efecto de la rotación de cultivos en la incidencia del amachamiento (Aphelenchoides besseyi Christie) en frijol. Agronomía Costarricense, 36, 61-70. https://www.redalyc.org/pdf/436/43625500005.pdf

[11] Verhulst, N., François, I. and Govaerts, B. (2015) Agricultura de conservación, mejora la calidad del suelo a fin de obtener sistemas de producción sustentables? Centro Internacional de Mejoramiento de Maíz y Trigo. $24 \mathrm{p}$. https://repository.cimmyt.org/xmlui/bitstream/handle/10883/4408/56985.pdf

[12] Taboada, M.A. and Varela, M.F. S/F. Impactos de las rotaciones de cultivos sobre los suelos.

https://www.aapresid.org.ar/wp-content/uploads/2014/12/RotaciondecultivosTaboa da.docx.pdf 
[13] Jiménez, J.O. (2013) Sorgo granífero. Condiciones relevantes en el Chaco. https://www.agrositio.com.ar/noticia/151478-sorgo-granifero-consideraciones-relev antes-en-el-chaco

[14] Voisin, A.I., Novillo, B.V. and Chamorro, A.M. (2018) Análisis de diferentes secuencias de cultivos: Aportes al sistema productivo. INTA. Revista de Investigaciones Agropecuarias, 44, 105-112.

[15] Carrasco, N., Zamora, M.Y. and Melin, A. (2011) Manual de sorgo. Instituto Nacional de Tecnología Agropecuaria. Argentina, 111.

https://inta.gob.ar/sites/default/files/inta_manual_de_sorgo_renglon_191.pdf

[16] Castillo, J., Macedo, I. and Terra, J. (2017) Balance de nutrientes de diferentes rotaciones arroceras manejadas con distintos criterios de rotación. Arroz. Serie técnica 233. Capitulo III. Instituto Nacional de Investigación agropecuaria. Uruguay, 69-71. https://www.researchgate.net/publication/350396311_BALANCE_DE_NUTRIENTES_ DE_DIFERENTES_ROTACIONES_ARROCERAS_MANEJADAS_CON_DISTINTOS _CRITERIOS_DE_FERTILIZACION

[17] Spehar, C.R. and Souza, P.I.M. (1997) Los sistemas de cultivos sostenibles en los Cerrados brasileños. Centro de Pesquisa Agropecuaria dos Cerrados. En: Gestión integral de cultivos. FAO, Roma, Italia. Colección técnica No. 1, 130. http://www.fao.org/3/v8941s/v8941s04.htm

[18] García, O.F. (2001) Soja: Criterios para la fertilización del cultivo. INPOFOS/PPI/PPIC Cono Sur. Acassuso-Argentina. 1-13. http://agro.unc.edu.ar/ ceryol/documentos/soja/Criterios_fertilizacion.pdf

[19] Schatz, B.G., Schneiter, A.A. and Gardner, J.E. (1990) Effect of Plant Density on Grain Sorghum Production in North Dakota. North Dakota Farm Research-North Dakota, Agricultural Experiment Station (USA), 15-17.

https://library.ndsu.edu/ir/bitstream/handle/10365/9561/farm_47_05_04.pdf?seque nce $=1$ \&isAllowed $=y$

[20] Blum (1970) Effect of Plant Density and Growth Duration on Grain Sorghum Yield under Limited Water Supply. Agronomy Journal, 62, 333-336.

https://acsess.onlinelibrary.wiley.com/doi/abs/10.2134/agronj1970.00021962006200 $030007 \mathrm{x}$ https://doi.org/10.2134/agronj1970.00021962006200030007x

[21] Wade, L.J. and Douglas, A.C.L. (1990) Effect of Plant Density on Grain Yield and Yield Stability of Sorghum Hybrids Differing in Maturity. Australian Journal of Experimental Agriculture, 30, 257-264. https://doi.org/10.1071/EA9900257 https://agris.fao.org/agris-search/search.do?recordID=AU9003039

[22] Berenguer, M.J. and Faci, J.M. (2001) Sorghum (Sorghum bicolor L. Moench) Yield Compensation Processes under Different Plant Densities and Variable Water Supply. European Journal of Agronomy, 15, 43-55.

https://www.sciencedirect.com/science/article/abs/pii/S1161030101000958 https://doi.org/10.1016/S1161-0301(01)00095-8

[23] Tabo, R., Olabanji, O.G., Ajayi, O. and Flower, D.J. (2001) Effect of Plant Population Density on the Growth and Yield of Sorghum Varieties Grown on a Vertisol. African Crop Science Journal, 10, 31-38. http://www.bioline.org.br/abstract?cs02004 https://doi.org/10.4314/acsj.v10i1.27555

[24] Rivero, B.N. (1998) Fertilización fosfórica y densidad de plantas en sorgo (Sorghum bicolor L Moeneh) y maíz (Zea mays L.) En el norte de Tamaulipas. Facultad de Agronomia. Universidad Autónoma de Nuevo León, México. Tesis de Maestro en Ciencias. 91 p. http://eprints.uanl.mx/6407/1/1080110319.PDF 
[25] Stevens, G. and Dunn, D. (2010) Fertilizacion de Sorgo para grano en Poblaciones Desuniformes. Revista Fertilizar, 16, 5-7. https://fertilizar.org.ar/wp-content/uploads/2020/09/16

[26] Torres, G.C.A., Gutiérrez, C.M.C., Ortiz, S.C.A. and Gutiérrez, C.E.V. (2016) Manejo agronómico de los Vertisoles en México: una revisión. Terra Latinoamericana, 34, 457-466. http://www.scielo.org.mx/pdf/tl/v34n4/2395-8030-tl-34-04-00457.pdf

[27] Sahrawat, K.L. (1999) Assessing the Fertilizer Phosphorus Requirement of Grain Sorghum. Communications in Soil Science and Plant Analysis, 30, 1953-1601. http://oar.icrisat.org/1804/1/ComSocSciPlantAnal30_11-12_1593-1601_1999.pdf https://doi.org/10.1080/00103629909370311

[28] Medina-Méndez, J., Volke, H.V.H., Galvis, S.A., González, R.J.M., Santiago, C.M.J. and Cortés, F.J.I. (2009) Propiedades químicas de un Luvisol después de la conversión del bosque a la agricultura en Campeche, México. Agronomía Mesoamericana, 20, 217-235. http://www.mag.go.cr/rev_meso/v20n2_217.pdf https://doi.org/10.15517/am.v20i2.4939

[29] Gambaudo, S. (2008) La fertilización del sorgo granífero. EEA INTA Rafaela. http://portal.acabase.com.ar/suelofertil/Artculos\%20de\%20Inters/SORGO/Sorgo $\% 2$ 0granifero\%20-\%20Nutrici\%C3\%B3n\%20del\%20cultivo.pdf

[30] FAO-UNESCO (Food and Agricultural Organization of United Nations) (1976) Mapa mundial de suelos 1:5000000. Vol. III. México y América Central. Organización de las Naciones Unidas para la Agricultura y la Alimentación-Organización de las Naciones Unidas para la Educación, Paris, 24-51.

http://www.fao.org/docrep/019/as358s/as358s.pdf

[31] Hernández, P.M. (2015) Agenda técnica agrícola de Campeche. Soya de temporal. INIFAP-CIRSE. Campo Experimental Edzná. 111-127.

https://issuu.com/senasica/docs/04_campeche_2015_sin/137

[32] Medina, M.J. (2015) Agenda técnica agrícola de Campeche. Maíz de temporal. INIFAP-CIRSE. Campo Experimental Edzná. 87-93.

https://issuu.com/senasica/docs/04_campeche_2015_sin/137

[33] Villalobos, G.A. (2015) Producción de sorgo para grano. In: Agenda Técnica Agrícola Campeche, Instituto Nacional de Investigaciones Forestales Agrícolas y Pecuarias, 93-102. https://issuu.com/senasica/docs/04_campeche_2015_sin/137

[34] Vázquez-Alarcón, A. (1997) Guía para interpretar el análisis químico del agua y suelo. 2nd Edition, Departamento de Suelos, Universidad Autónoma Chapingo, México. http://www.scielo.org.mx/scieloOrg/php/reflinks.php?refpid=S0188-4611200900020 000200052\&lng=en\&pid=S0188-46112009000200002

[35] Magallanes, E.A., Díaz, F.A., Reyes, R.M.A., Rosales, R.E., Alvarado, C.M., Silva, S.M.M., Bustamante, D.A.J. and Cortinas, E.H.M. (2014) Tecnología de producción en soya [Glycine $\max (\mathrm{L}$.$) Merrill] para el norte de Tamaulipas. INIFAP/CIRNE.$ Folleto Técnico No. MX-0-310301-47-03-13-09-58. 36 p.

http://www.inifapcirne.gob.mx/Biblioteca/Publicaciones/991.pdf

[36] Pacheco, C.J.J. (2016) Identificación de Plagas de la Soya. Memoria del Curso: Principales plagas de la soya en el Noroeste de México. INIFAP-CIRNO. 13 p. http://jlsvyaqui.org.mx/wordpress/wp-content/uploads/Memorias/2016/PLAGAS\% 20SOYA\%20IDENTIFICACI\%C3\%93N.pdf

[37] Zamora, M., Melin, A.L. and Balda, S. (2009) Manejo del cultivo del sorgo. Efecto de la densidad y la fertilización. INTA. B. A. Argentina.

https://inta.gob.ar/sites/default/files/script-tmp-densidad_y_fertilizacin_en_sorgo.p df 
[38] Cicchino, M. (2015) Efecto de la densidad de siembra sobre el rendimiento de sorgo granífero en el norte de la cuenca del Salado. III Simposio Nacional. I Conferencia Internacional de Sorgo. 3 p.

https://inta.gob.ar/sites/default/files/densidad_de_siembra_y_rendimiento_en_sorg o.pdf

[39] Perales, R.D. (2019) Caracterización del pulgón amarillo del sorgo (Melanaphis saccharil sorghi) Zehntner, en el cultivo de sorgo (Sorghum bicolor (L.) Moench, en el estado de morelos. Tesis de Doctor en Ciencias, Universidad Autónoma del Estado de Morelos, México, $61 \mathrm{p}$.

http://riaa.uaem.mx/xmlui/bitstream/handle/20.500.12055/998/PERDSN00T.pdf?se quence $=1$ \&isAllowed $=\mathrm{y}$

[40] Rodríguez, B.L.A. and Terán, V.A.P. (2014) Control químico del pulgón amarillo del sorgo. Tecnología generada. SAGARPA-INIFAP. Campo Experimental Río Bravo. 2 p.

http://inifapcirne.gob.mx/Eventos/2015/PULG\%C3\%93N\%20AMARILLO\%20SOR GO.pdf

[41] Cortez, M.E. (2018) Manejo del pulgón amarillo en sorgo. INFAP/CIRNO. Campo Experimental Valle del Fuerte. https://panorama-agro.com/?p=3163

[42] Mixquititla, C.G. and Villegas, T.O. (2016) Importancia de los fosfatos y fosfitos en la nutrición de cultivos. Acta Agrícola y Pecuaria, 2, 55-61.

https://webcache.googleusercontent.com/search?q=cache:A894nzGsXasJ:https://dial net.unirioja.es/descarga/articulo/6201359.pdf $+\& \mathrm{~cd}=4 \& \mathrm{hl}=\mathrm{es}-419 \& \mathrm{ct}=\mathrm{clnk} \& \mathrm{gl}=\mathrm{mx}$

[43] Álvaro, G.J. (2019) El fósforo y su importancia en el crecimiento Vegetal. FERTIBOX, Análisis agrícolas, Fertilización. https://www.fertibox.net/single-post/fosforo-agricultura

[44] Gerik, T.B. and Vanderlip, R. S/F. Sorghum Growth and Development. Texas Cooperative Extension. Texas A\&M University System. 7 p. http://glasscock.agrilife.org/files/2015/05/Sorghum-Growth-and-Development.pdf

[45] Steduto, P., Hsiao, T.C., Fereres, E. and Raes, D. (2014) Respuesta del rendimiento de los cultivos al agua. Estudio Riego y Drenaje 66. Organización de las Naciones Unidas para la Alimentación y la Agricultura. Roma Italia. 33.

http://www.fao.org/3/a-i2800s.pdf

[46] INEGI (2017) Instituto Nacional de Estadística y Geografía. Anuario estadístico y geográfico de Campeche 2017.

https://www.datatur.sectur.gob.mx/ITxEF_Docs/CAM_ANUARIO_PDF.pdf

[47] Pérez, A., Saucedo, O., Iglesias, J., Hilda, B., Wencomo, H.B., Reyes, G.F., Oquendo, G. and Milián, I. (2010) Caracterización y potencialidades del grano de sorgo (Sorghum bicolor L. Moench). Pastos y Forrajes, 33, 1-17. http://scielo.sld.cu/pdf/pyf/v33n1/pyf01110.pdf

[48] Rangarajan, A. (2012) Crop Rotation Effects on Soil Fertility and Plant Nutrition. Sustainable Agriculture Research \& Education.

https://www.sare.org/Learning-Center/Books/Crop-Rotation-on-Organic-Farms/Te xt-Version/Physical-and-Biological-Processes-In-Crop-Production/Crop-RotationEffects-on-Soil-Fertility-and-Plant-Nutrition 